\title{
Polar science news in brief
}

\author{
David Carlson
}

(C) Springer-Verlag Berlin Heidelberg 2013

The addition of the "News in Brief" series to our Views and News section will highlight recent significant research in the last year-from high-impact papers to emerging research fronts-and will include papers with both classic and new hot topics. This series will offer a rotating view among the major Earth Science areas, as various experts will be invited to provide a brief look around the recent research conducted in their area. This selection of research papers is left up to each expert and due to the broadness of each field is not intended to be a comprehensive overview. Links to the published work are provided in each section. David Carlson, former Director of the International Programme Office for the International Polar Year, has been invited to provide a glimpse into the latest findings in polar science. Carlson outlines selected research of global relevance hoping that readers will "discover the fascinating connections among and across these topics, and the unintended prominence of three restless partners: ocean, wind and ice".

\section{Ocean circulation}

The interior Arctic Ocean continues to get warmer, particularly in layers influenced by incoming Atlantic water (Polyakov et al. 2012). The present warming exceeds anything recorded in instrumental records for the Arctic

Electronic supplementary material The online version of this article (doi:10.1007/s12665-012-2185-y) contains supplementary material, which is available to authorized users.

D. Carlson $(\bowtie)$

Boulder, CO, USA

e-mail: ipy.djc@gmail.com
Ocean. Within the Canadian basin, ocean currents, ice movements and river outflow trajectories all suggest that anti-cyclonic winds have forced a change from cyclonic (counter-clockwise in $\mathrm{NH}$ ) to anticyclonic (clockwise) flow in the surface currents of the Beaufort Gyre (Melling et al. 2012), a change that penetrates to intermediate layers. Tracking radioisotopes released in UK and France, Karcher et al. (2012) show that Atlantic water, rather than circulating counterclockwise along the Siberian shelf, now takes a shorter route across the central Arctic and then clockwise along the Beaufort shelf. If persistent, such a change in circulation will drive new upwelling regimes along the shallow shelf regions of Beaufort and Siberian coasts. The net impacts of Arctic warming and circulation changes on the Pacific through Arctic to Atlantic mean flow, on the net heat and freshwater balance of the Arctic, and on Arctic inputs to the North Atlantic remain uncertain. Bamber et al. (2012) report a steady and substantial increase of freshwater from Greenland into the Irminger Sea, one of the regions where freshwater inputs impact vertical density structure and North Atlantic deepwater formation (Fig. 1).

In the Southern Ocean, where south-flowing North Atlantic deepwaters rise to the surface and Antarctic bottom waters form and flow northwards, Antarctic bottom water has warmed significantly over more than 20 years, implying a slowing of Antarctic contributions to the deep circulation system (Purkey and Johnson 2012). Gordon et al. (2010) report strong seasonal and inter-annual variability in one of the largest of those contribution regions, the Weddell Sea, tied to regional wind patterns. Local and region-wide winds also influence upwelling of the North Atlantic source waters near Antarctica (Marshall and Speer 2012). Meredith et al. (2012) looked closely at the freshwater system around the Antarctic Peninsula, a region of rapid warming, using $\mathrm{O}_{2}$ isotopes to distinguish meteoric 


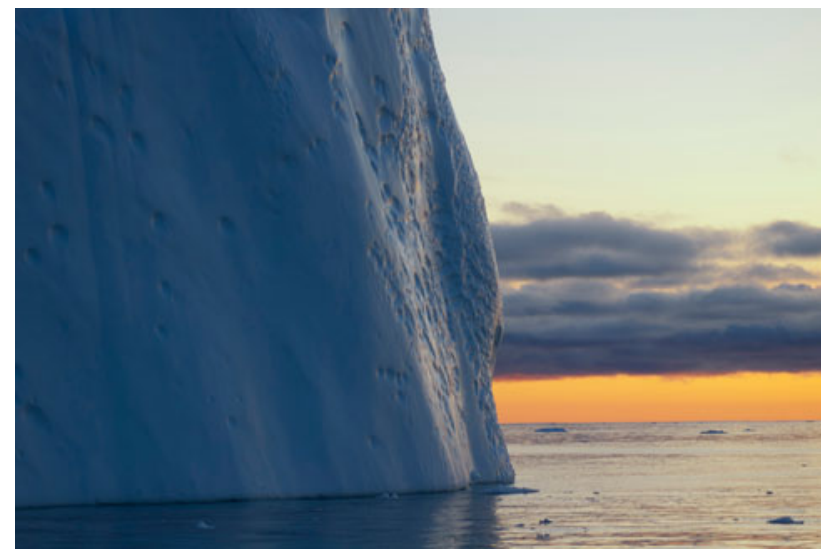

Fig. 1 Icebergs from Sermeq Kujalleq (Jakobshavn Isbræ), near Ilulissat, west Greenland, 2008, a UNESCO World Heritage Site at 69.07.60N 49.30.00W. Photo: David Carlson, IPY IPO

(glacial, precipitation) water from sea ice meltwater. Over a decade they monitored a decrease in meteoric water despite increases of both precipitation and glacial melt, indicating increased wind-driven ocean mixing with consequences for biology. Because local and regional patterns link to circum-Antarctic Southern Ocean wind patterns, which in turn link to tropical Pacific conditions, hemispheric and global influences play a strong role in determining polar contributions to deep ocean circulation. Wind and ice influence ocean; ocean and wind influence ice.

\section{Track down the details at:}

- Bamber J et al. (2012) Recent large increases in freshwater fluxes from Greenland into the North Atlantic. Geophys Res Lett. doi:10.1029/2012GL 052552

- Karcher M et al. (2012) Recent changes in Arctic Ocean circulation revealed by iodine-129 observations and modeling. J. Geophys. Res. doi:10.1029/2011JC 007513

- Gordon AL, Huber B, McKee D, Visbeck M (2010) A seasonal cycle in the export of bottom water from the Weddell Sea. Nature Geoscience. doi:10.1038/ngeo916

- Marshall J, Speer K (2012) Closure of the meridional overturning circulation through Southern Ocean upwelling. Nature Geoscience. doi:10.1038/ngeo1391

- Melling H et al. (2012) The Arctic Ocean-a Canadian perspective from IPY. Climatic Change. doi:10.1007/ s10584-012-0576-4

- Meredith MP et al. (2012) The freshwater system west of the Antarctic Peninsula: spatial and temporal changes. J. Climate. doi:10.1175/JCLI-D-12-00246.1

- Polyakov IV, Pnyushkov AV, Timokhov LA (2012) Warming of the intermediate Atlantic Water of the Arctic Ocean in the 2000s. Journal of Climate. doi: 10.1175/JCLI-D-12-00266.1
- Purkey SG, Johnson GC (2012) Global Contraction of Antarctic Bottom Water between the 1980s and 2000s. J. Climate. doi:10.1175/JCLI-D-11-00612.1

\section{Under the ice}

Around the perimeter of Antarctica, where ocean, wind and ice perform their complicated dance, an interesting story emerges. From above, satellite radar altimetry since 2002 shows accelerated thinning (Flament and Rémy 2012) around the Amundsen Sea, including Pine Island and Thwaites glacial ice streams, but not elsewhere. Comparing radar images from 1997 with repeat images from 2009, Scheuchl et al. (2012) likewise observe only small surface ice velocity changes for ice streams draining onto the Ross and Filchner-Ronne Ice Shelves; they recommend continued close observation particularly of the West Antarctic ice streams draining onto the Ross Ice Shelf. Using laser altimetry, with better coverage and smaller measurement footprints relative to radar, Pritchard et al. document thinning on 20 of 54 Antarctic ice shelves, most vigorously but not exclusively around the Amundsen and Bellingshausen Seas. Because ice shelves buttress their tributary glaciers, melt-induced thinning of the ice shelves drives a corresponding thinning and acceleration of the upstream glaciers (Pritchard et al. 2012). Looking beneath those ice shelves, Hattermann et al. (2012) observed consistently cold ocean temperatures for 2010 and 2011 under the Fimbul Ice Shelf, indicating low amounts of basal melting; heat for such basal melting as occurs comes from wind-forced incursions of deeper and warmer water and from local surface waters warmed by summer sun. Along the Amundsen and Bellingshausen Seas, however, wind-driven changes in supply and proximity of warm ocean water drive substantial changes (Pritchard et al. 2012). Vaughn et al. (2012), combining high-resolution radar surveys from the surface with upward-looking acoustic data from below, discovered extensive melt-induced subglacial channels under Pine Island Glacier, aligned with and linked to within-ice crevasses at both the base and the surface-bottom melt influences the structural integrity of the entire glacier. (Harper et al. 2010, using radar and seismic surveys, show similar cavities in Alaskan glaciers, with basal hydrologic systems penetrating far into the glacier mass.) Bingham et al. (2012) show that the inland course and extent of, for example, troughs under Pine Island Glacier, follow tectonic rifts. The rift systems, some of them sloping inward (landward), represent preferred routes for warm water penetration. Basal melting has eroded and expanded a cavity under the Pine Island Ice Shelf, allowing more 
warm seawater (as warm as $4{ }^{\circ} \mathrm{C}$ ) to access the underside (Jacobs et al. 2011). Meltwater input to the surrounding ocean appears to have increased by $50 \%$ over a decade (Jacobs et al. 2011). Ross et al. (2012) describe a newly discovered large subglacial basin deep in the interior of the Weddell Sea, under the present day Filchner Ice Shelf and its tributary glaciers. The basin slopes steeply inland and lies just upstream of present-day grounding lines for several tributary glaciers. By coupling a regional ice-ocean model with a global climate model, Hellmer et al. (2012) show a plausible redirection of warm coastal ocean currents into the Filchner trough beneath the Filcher-Ronne shelves. As a consequence, basal melting increases by a factor of 20. In their model, regional changes in ocean currents derive from larger-scale changes in wind forcing across the Weddell Sea as sea ice thins and disperses over a warmer ocean. Humbert (2012) provides a more detailed but very readable summary of Weddell Sea predictions. In general, a consistent picture emerges around Antarctica of ice and ice shelves responding rapidly via the ocean to changes in Southern Hemisphere wind patterns (Pritchard et al. 2012), patterns that themselves vary on timescales of years to decades in concert with global features such as El Niño-Southern Oscillation (ENSO).

For Greenland, a new comprehensive satellite view shows that marine-terminating glaciers drain nearly $90 \%$ of the Greenland ice mass and that under-ice motions (basal sliding) play a very large role in dynamics of the ice sheet (Rignot and Mouginot 2012). By monitoring on-ice GPS displacements, Sole et al. (2011) show that efficient subglacial drainage of a marine terminating glacier extended at least $48 \mathrm{~km}$ inland during one melt season. Satellite (Sundal et al. 2011) and on-surface (Bartholomew et al. 2010) GPS measurements indicate a seasonal interplay between melt and subglacial drainage, with substantial inter-annual variability; models of ice motion for the Greenland ice sheet will need to capture these interacting processes. An ice flow model used by Wang et al. (2012) showed that mass losses at the Greenland margin cause thinning higher on the continent on decadal time scales, thinning that can persist for centuries. Exploiting the time and position accuracy of GPS systems anchored to exposed bedrock at the perimeters of Greenland, Bevis et al. (2012) measured vertical uplift, in excess of postglacial rebound, due to rapid crustal response to recent ice mass losses. Their GPS network also records uplift 'pulses' correlated with short-lived events such as seasonal surface melt anomalies. Nghiem et al. (2012) document another remarkable surface melt event for 2012. From these reports we sense the Greenland Ice Sheet interacting extensively and rapidly with surrounding ocean (Fig. 2) and overlying atmosphere.

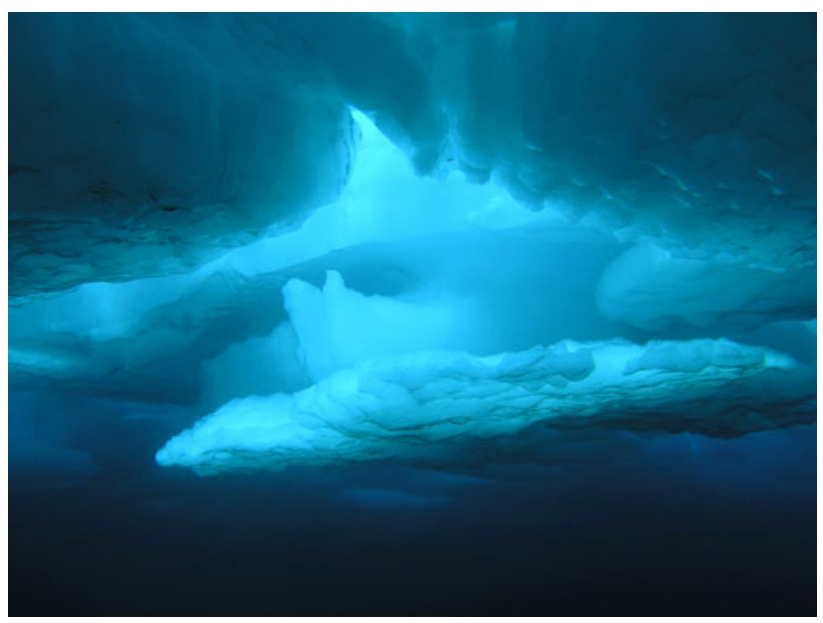

Fig. 2 Sea ice from below, taken in the Canada Basin during the Census of Marine Life. Photo: Elizabeth Calvert, NOAA (USA), http://news.coml.org/medres/Iceocean/iceocean.htm

\section{Track down the details at:}

- Bartholomew I et al. (2010) Seasonal evolution of subglacial drainage and acceleration in a Greenland outlet glacier. Nature Geoscience. doi:10.1038/ngeo863

- Bevis M et al. (2012) Bedrock displacements in Greenland manifest ice mass variations, climate cycles and climate change. PNAS. doi:10.1073/pnas. 120466 4109

- Bingham RG et al. (2012) Inland thinning of West Antarctic Ice Sheet steered along subglacial rifts. Nature. doi:10.1038/nature11292

- Flament T, Rémy F (2012) Dynamic thinning of Antarctic glaciers from along-track repeat radar altimetry. J Glaciology. doi:10.3189/2012JoG11J118

- Harper JT, Bradford JH, Humphrey NF, Meierbachtol TW (2010) Vertical extension of the subglacial drainage system into basal crevasses. Nature. doi:10.1038/ nature 09398

- Hattermann T, Nøst OA, Lilly JM, Smedsrud LH (2012) Two years of oceanic observations below the Fimbul Ice Shelf, Antarctica. Geophys Res Lett. doi: 10.1029/2012GL051012

- Hellmer HH et al. (2012) Twenty-first-century warming of a large Antarctic ice-shelf cavity by a redirected coastal current. Nature. doi:10.1038/nature11064

- Humbert A (2012) Cryospheric science: Vulnerable ice in the Weddell Sea. Nature Geoscience. doi:10.1038/ ngeo 1484

- Jacobs SS, Jenkins A, Giulivi CF, Dutrieux P (2011) Stronger ocean circulation and increased melting under Pine Island Glacier ice shelf. Nature Geoscience. doi: 10.1038/ngeo1188 
- Ngheim SV et al. (2012) The Extreme Melt across the Greenland Ice Sheet in 2012. Geophys Res Lett. doi: 10.1029/2012GL053611

- Pritchard HD et al. (2012) Antarctic ice-sheet loss driven by basal melting of ice shelves. Nature. doi: 10.1038/nature10968

- Rignot E, Mouginot J (2012) Ice flow in Greenland for the International Polar Year 2008-2009. Geophys Res Lett. doi:10.1029/2012GL051634

- Ross N et al. (2012) Steep reverse bed slope at the grounding line of the Weddell Sea sector in West Antarctica. Nature Geoscience. doi:10.1038/ngeo1468

- Scheuchl B, Mouginot J, Rignot E (2012) Ice velocity changes in the Ross and Ronne sectors observed using satellite radar data from 1997 and 2009. The Cryosphere. doi:10.5194/tc-6-1019-2012

- Sole AJ et al. (2011) Seasonal speedup of a Greenland marine-terminating outlet glacier forced by surface melt-induced changes in subglacial hydrology. J Geophys Res. doi:10.1029/2010JF001948

- Sundal AV et al. (2011) Melt-induced speed-up of Greenland ice sheet offset by efficient subglacial drainage. Nature. doi:10.1038/nature09740

- Vaughan DG et al. (2012) Subglacial melt channels and fracture in the floating part of Pine Island Glacier, Antarctica. J Geophys Res. doi:10.1029/2012JF002360

- Wang W, Li J, Zwally J (2012) Dynamic inland propagation of thinning due to ice loss at the margins of the Greenland ice sheet. J Glaciology. doi:10.3189/ 2012JoG11J187

\section{Ocean acidification}

Measurements (taken as part of Canada's IPY program) showed Arctic waters already undersaturated with respect to aragonite (Yamamoto-Kawai et al. 2011, Azetsu et al. 2010), one of the biologically preferred forms of carbonate. $\mathrm{CO}_{2}$ in these sub-surface waters came from recent atmospheric $\mathrm{CO}_{2}$ and from recent melting of sea ice (Yamamoto-Kawai et al. 2011) with additional impacts from organic matter remineralization (Melling et al. 2012). Reduced $\mathrm{CO}_{2}$ solubility as a consequence of recent warming did not offset the $\mathrm{CO}_{2}$ increases. In a large-scale model, rapid reductions in sea ice caused enhanced air-tosea $\mathrm{CO}_{2}$ transfer and increased freshwater inputs to the Arctic Ocean; both factors lead to lower $\mathrm{pH}$ and greater aragonite under-saturation (Yamamoto et al. 2012). Matson et al. (2011) reported novel high-frequency measurements of $\mathrm{pH}$ under shore-fast sea ice in the Ross Sea; such measurements will prove increasingly valuable to understand temporal and spatial $\mathrm{pH}$ variations. McNeil et al. (2010) suggest that persistent sea ice coverage, coupled with winter-time deepwater entrainment, will moderate the atmospheric $\mathrm{CO}_{2}$ impact on Ross Sea $\mathrm{pH}$ for several decades; away from the continent, exposed expanses of the Southern Ocean will not benefit from such a reprieve. Many papers, too numerous to track or cite, explore $\mathrm{pH}$ impacts on polar organisms from both hemispheres, from benthic echinoderms to planktonic bacteria. These studies vary widely in: life stage of target organism; treatment; duration; and phenological, physiological or behavioral response measured. Some evaluate $\mathrm{pH}$ together with temperature, or together with nutrient availability. Most of the studies show some degree of resilience to moderate decreases in $\mathrm{pH}$, with significant and acute impacts appearing at maximum $\mathrm{CO}_{2}$ /lowest $\mathrm{pH}$ expected values. Often, lowered $\mathrm{pH}$ and warming temperatures together provoke a substantial biological response. Assembling these experiments and treatments into a consistent and coherent picture will require that the polar acidification community adopt methodologies for standardization and inter-comparison already in use in toxicology assessments. Ocean conditions, modified by ice and wind, will determine $\mathrm{pH}$ exposures and ecosystem responses.

\section{Track down the details at:}

- Azetsu SK et al. (2010) Calcium carbonate saturation states in the waters of the Canadian Arctic Archipelago and the Labrador Sea. J Geophys Res. doi:10.1029/ 2009JC005917

- Matson PG, Martz TR, Hofmann GE (2011) Highfrequency observations of $\mathrm{pH}$ under Antarctic sea ice in the southern Ross Sea. Antarctic Science. doi:10.1017/ S0954102011000551

- McNeil BI, Tagliabue A, Sweeney C (2010) A multidecadal delay in the onset of corrosive 'acidified' waters in the Ross Sea of Antarctica due to strong air-sea $\mathrm{CO}_{2}$ disequilibrium. Geophys Res Lett. doi: 10.1029/2010GL044597

- Melling $\mathrm{H}$ et al. (2012) ibid. doi:10.1007/s10584012-0576-4

- Yamamota A et al. (2012) Impact of rapid sea-ice reduction in the Arctic Ocean on the rate of ocean acidification. Biogeosciences. doi:10.5194/bg-9-2365-2012

- Yamamoto-Kawai M, McLaughlin FA, Carmack EC (2011) Effects of ocean acidification, warming and melting of sea ice on aragonite saturation of the Canada Basin surface water, Geophys Res Lett. doi:10.1029/ 2010GL045501

\section{Weather}

After another summer of remarkable shrinkage of Arctic sea ice extent, researchers will attempt to discern the separate 
and combined influences of warmer ocean and stronger winds. As I predicted in February 2012 (Carlson 2012), more and more researchers and forecasters turn their attention to the causes, consequences and hemispheric connections of reduced sea ice and increased exposed ocean. By monitoring sharp gradients of ozone at the subtropical and polar fronts, Hudson (2012) documents a global poleward shift of the jet streams, a latitudinal shift that will impact temperature and precipitation patterns in both hemispheres. Several research groups (Balmaseda et al. 2010, Overland et al. 2012, Jaiser et al. 2012, Yang and Christensen 2012) looked at consequences of Arctic sea ice anomalies on hemispheric, North American and Eurasian atmospheric pressure fields and circulation patterns, and even at correlations with the composite effects of Atlantic tropical cyclones (Scoccimarro et al. 2012). Changes in regional snow cover, analogous to sea ice changes in that the reduction of a reflective and insulating surface-ice, snow-exposes a darker, warmer and often interactive substrate-land or ocean, also apparently influence subsequent specific events such as Asian dust storms (Lee et al. 2012) and larger scale atmospheric patterns both upstream and downstream of the snow regions (Henderson et al. 2012). Often these studies diagnose altered wind patterns over the central Arctic, high pressure (and clear skies, ideal for surface melting!) over Greenland, and frequent winter cold events (on top of a pattern of general warming) for Europe. Converting these initial correlations and speculations into predictive skill remains a difficult challenge because of short records amidst large variability, the daunting task of extracting confirmation from correlation and continued uncertainty of future conditions (Screen et al. 2012). We see the major players-wind, ice and ocean-in both hemispheres, but surprises lie ahead.

\section{Track down the details at:}

- Balmaseda MA, Ferranti L, Franco M, Palmer TN (2010) Impact of 2007 and 2008 Arctic ice anomalies on the atmospheric circulation: Implications for longrange predictions. Quart J Roy Met Soc. doi:10.1002/ qj.661

- Carlson D (2012) Polar knowledge and global action at the close of the International Polar Year. Environ Earth Sci. doi:10.1007/s12665-011-1499-5

- Henderson GR, Leathers DJ, Hanson B (2012) Circulation response to Eurasian versus North American anomalous snow scenarios in the Northern Hemisphere with an AGCM coupled to a slab ocean model. J Climate. doi:10.1175/JCLI-D-11-00465.1

- Hudson RD (2012) Measurements of the movement of the jet streams at mid-latitudes, in the Northern and Southern Hemispheres, 1979 to 2010. Atmos Chem Phys. doi:10.5194/acp-12-7797-2012
- Jaiser R et al. (2012) Impact of sea ice cover changes on the Northern Hemisphere atmospheric winter circulation. Tellus. doi:10.3402/tellusa.v64i0.11595

- Lee YG, Ho C-H, Kim J, Kim J (2012) Potential impacts of northeastern Eurasian snow cover on generation of dust storms in northwestern China during spring. Climate Dynamics. doi:10.1007/s00382-0121522-X

- Overland JE, Francis JA, Hanna E, Wang M (2012) The recent shift in early summer Arctic atmospheric circulation. Geophys Res Lett. doi:10.1029/2012GL 053268

- Scoccimarro E, Gualdi S, Navarra A (2012) Tropical cyclone effects on Arctic Sea ice variability. Geophys Res Lett. doi:10.1029/2012GL052987

- Screen JA, Simmonds I, Deser C, Tomas R (2012) The atmospheric response to three decades of observed Arctic sea ice loss. J Climate. doi:10.1175/JCLI-D-1200063.1

- Yang S, Christensen JH (2012) Arctic sea ice reduction and European cold winters in CMIP5 climate change experiments, Geophys Res Lett. doi:10.1029/2012GL 053338

\section{Carbon}

Alerted by revised and increased carbon pools and exchange processes identified in polar regions (short summary in Carlson 2012), attention turns to carbon cycle sources and sinks from polar marine (Arctic and Antarctic), submarine (largely Arctic), and terrestrial (Arctic) systems. Based on a full season of measurements in fractional ice and open lead conditions, Barber et al. (2012) point out that processes of ice formation and brine rejection, the temperatures and permeabilities of the resulting ice, and the presence and activity of ice algae collectively result in very active carbon exchanges, summer and winter, at rates far different than predicted for solid ice or open ocean conditions. These ice formation processes, their seasonal and annual extent in the present and future Arctic (and Antarctic), and their interactions with present and future mixing and deepwater formation processes in the underlying ocean represent an important term in global carbon cycles. Looking at those same surface to deep carbon exchange processes in the Southern Ocean (albeit north of Antarctic marginal sea ice zones), Sallee et al. (2012) echo this conclusion: wind-driven ocean mixing and deep ocean currents drive the important carbon processes.

In assessing net carbon production or sequestration in Arctic terrestrial environments, air and soil temperatures and soil moisture appear to represent the dominant factors 
in vegetated environments (Cahoon et al. 2012; Ge et al. 2012, Myers-Smith et al. 2011). Regional carbon projections thus depend strongly on local and regional predictions of temperature and precipitation, predictions made more difficult by changing atmospheric circulations identified above. Vonk et al. (2012) identify erosion of buried ice-age deposits, exposed along the Siberian coast and near-shore sea floor and rich in organic carbon, as the dominant source of carbon to surface sediments along the Siberian coast and as a substantial source of $\mathrm{CO}_{2}$ to the atmosphere. Increased thawing and increased coastal erosion will mobilize more of this old carbon. Northern urban areas remain predominantly carbon sources (Jarvi et al. 2012), although, interestingly, a Finnish study shows that cities that incorporate greater fractions of natural (vegetated) areas tend to have lower carbon emissions (Nordbo et al. 2012).

A new and more complicated picture emerges for methane. Most surprising, Wadham et al. (2012) demonstrate the potential for methane production and methane hydrate accumulation in sedimentary basins beneath Antarctic ice. Their findings raise the possibility that the total Antarctic sub-ice methane inventory could approach amounts estimated for Arctic permafrost! Research groups in the Arctic begin to refine the details, including temporal, spatial and environmental variability, of $\mathrm{CH}_{4}$ sources and sinks in lakes (Gentzel et al. 2012, presently a net source), tundra wetlands (Tagesson et al. 2012, a source if warmer and wetter), existing forests (Sundqvist et al. 2012, presently a sink) and the Arctic Ocean (Damm et al. 2010, potentially a source). A large-scale airborne survey over the western Arctic (Kort et al. 2012) demonstrated $\mathrm{CH}_{4}$ sources largely over open water channels and regions of fractional ice coverage, exactly those chemically and biologically active regions discussed by Barber et al. 2012 (above). From terrestrial (not including coastal or sea floor) permafrost, Burke et al. (2012) estimate that carbon emissions (as $\mathrm{CO}_{2}$ and $\mathrm{CH}_{4}$ ), under RCP (representative concentration pathway) 8.5 will add an additional 0.1 to perhaps $0.4{ }^{\circ} \mathrm{C}$ of warming by 2100 , with substantial uncertainties due to inadequate model representation of frozen soils. Using slightly higher carbon emission rates (with almost a factor of 10 uncertainty and still considering only terrestrial sources) and incorporating feedback between permafrost carbon emission and climate, MacDougall et al. (2012) project a warming due to terrestrial permafrost thaw of 0.1 to $1.6{ }^{\circ} \mathrm{C}$, under moderate $\mathrm{RCP}$ scenarios, by 2300 . Koven et al. (2012) evaluated current climate models for their ability to predict permafrost temperatures (none of those models predicts carbon emissions) and identified vertical soil temperature coupling, snow physics, and soil hydrology as major uncertainties-no surprise to permafrost researchers. Biastoch et al. (2011) modeled bottom water temperatures for the future
Arctic Ocean (next 100 years), including the likely geographic extent of warming waters over shallow regions known to contain methane hydrates. They projected sufficient methane release in the short (100 year) term to perhaps double the ocean acidification problem in parts of the Arctic. Over longer terms they estimate a maximum of $0.8^{\circ} \mathrm{C}$ increase in global surface air temperature from Arctic sea floor hydrates. Global methane emission and mitigation studies need to incorporate the improved Arctic source estimates. Höglund-Isaksson's (2012) estimate of methane emissions and mitigation costs through 2030 does not include Arctic marine, coastal or terrestrial terms, even though each permafrost source equals or exceeds other included emission sources. Stolaroff et al. (2012) recognize the Arctic challenges in their discussion of capture and mitigation strategies, and point out the need to better detect and quantify amounts of methane releases and better understand methanotroph and methanogen ecology, recommendations that will come as no surprise to Arctic oceanographers and limnologists.

\section{Track down the details at:}

- Barber DG et al. (2012) Consequences of change and variability in sea ice on marine ecosystem and biogeochemical processes during the 2007-2008 Canadian International Polar Year program. Climatic Change. doi:10.1007/s10584-012-0482-9

- Biastoch A et al. (2011) Rising Arctic Ocean temperatures cause gas hydrate destabilization and ocean acidification. Geophys Res Lett. doi:10.1029/2011 GL047222

- Burke EJ, Hartley IP, Jones CD (2012) Uncertainties in the global temperature change caused by carbon release from permafrost thawing. The Cryosphere. doi: 10.5194/tc-6-1063-2012

- Cahoon SMP et al. (2012) Interactions among shrub cover and the soil microclimate may determine future Arctic carbon budgets. Ecology Letters. doi:10.1111/ j.1461-0248.2012.01865.x

- Carlson D (2012) ibid. doi:10.1007/s12665-011-1499-5

- Damm E et al. (2010) Methane production in aerobic oligotrophic surface water in the central Arctic Ocean. Biogeosciences. doi:10.5194/bg-7-1099-2010

- Ge Z-M et al. (2012) Impacts of climate change on primary production and carbon sequestration of boreal Norway spruce forests: Finland as a model. Climatic Change. doi:10.1007/s10584-012-0607-1

- Gentzel T, Hershey AE, Rublee PA, Whalen SC (2012) Net sediment production of methane, distribution of methanogens and methane-oxidizing bacteria, and utilization of methane-derived carbon in an arctic lake. Inland Waters. Vol 2, No 2: 77-88. https://www. fba.org.uk/journals/index.php/IW/article/view/416 
- Höglund-Isaksson L (2012) Global anthropogenic methane emissions 2005-2030: technical mitigation potentials and costs. Atmos Chem Phys. doi:10.5194/ acp-12-9079-2012

- Järvi L et al. (2012) Seasonal and annual variation of carbon dioxide surface fluxes in Helsinki, Finland, in 2006-2010. Atmos Chem Phys. doi:10.5194/acp-128475-2012

- Kort EA et al. (2012) Atmospheric observations of Arctic Ocean methane emissions up to $82^{\circ}$ north. Nature Geoscience. doi:10.1038/ngeo1452

- Koven CD, Riley WJ, Stern A (2012) Analysis of permafrost thermal dynamics and response to climate change in the CMIP5 Earth System Models. J Climate doi:10.1175/JCLI-D-12-00228.1

- MacDougall AH, Avis CA, Weaver AJ (2012) Significant contribution to climate warming from the permafrost carbon feedback. Nature Geoscience. doi:10.1038/ngeo1573

- Myers-Smith IH et al. (2011) Shrub expansion in tundra ecosystems: dynamics, impacts and research priorities. Environ Res Lett. doi:10.1088/1748-9326/6/4/045509

- Nordbo A et al. (2012) Fraction of natural area as main predictor of net $\mathrm{CO}_{2}$ emissions from cities. Geophys Res Lett. doi:10.1029/2012GL053087

- Sallee J-B, Matear RJ, Rintoul SR, Lenton A (2012) Localized subduction of anthropogenic carbon dioxide in the Southern Hemisphere oceans. Nature Geoscience. doi:10.1038/ngeo1523

- Stolaroff JK et al. (2012) Review of methane mitigation technologies with application to rapid release of methane from the Arctic. Environ Sci Technol. doi: 10.1021/es204686w

- Sundqvist E et al. (2012) Atmospheric methane removal by boreal plants. Geophys Res Lett. doi: 10.1029/2012GL053592

- Tagesson T et al. (2012) Land-atmosphere exchange of methane from soil thawing to soil freezing in a highArctic wet tundra ecosystem. Global Change Biology. doi:10.1111/j.1365-2486.2012.02647.x

- Vonk JE et al. (2012) Activation of old carbon by erosion of coastal and subsea permafrost in Arctic Siberia. Nature. doi:10.1038/nature11392

- Wadham JL et al. (2012) Potential methane reservoirs beneath Antarctica. Nature. doi:10.1038/nature11374

\section{Cool crustaceans}

As in Carlson 2012, I focus on Arctic calanoid copepods (Fig. 3) and Antarctic krill because of the unique and essential role these energy-rich crustaceans play in polar

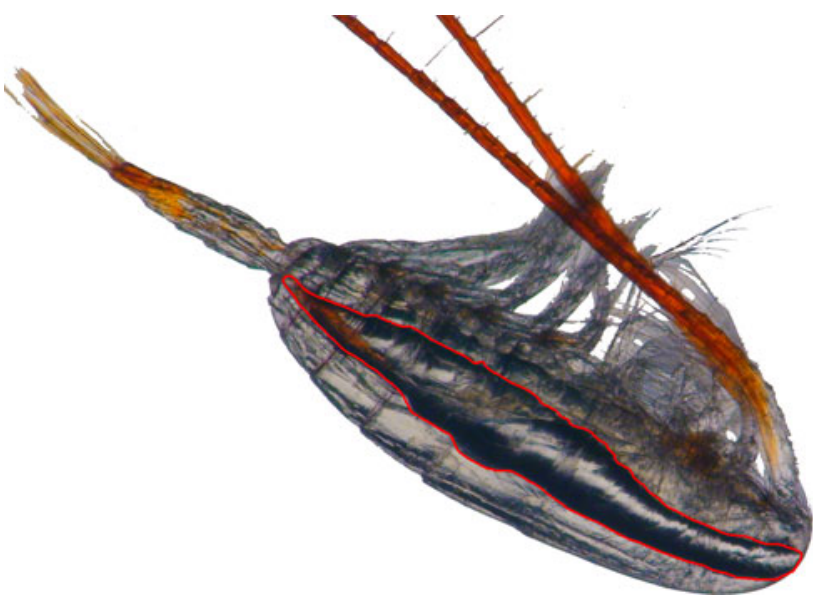

Fig. 3 An Arctic Calanoid copepod, length of carapace 6-7 mm, with outline of lipid sac. Image courtesy of D Vogedes, University Centre in Svalbard (UNIS)

ecosystems. Large-scale changes in Arctic or Antarctic ocean stratification, mixing and ice coverage will change the abundance and quality of food sources available to these keystone species (Tremblay et al. 2012, Murphy et al. 2012). In Arctic fjord systems, synchrony for reproductive adults with early-season ice algal blooms and for offspring with later post-ice pelagic blooms ensures overall annual and long-term success (Leu et al. 2011); ice break-up too early or too late disrupts these patterns. Over coastal shelf regions of the western Arctic, when and where wind has swept away sea ice, the number and intensity of upwelling events may provide extended albeit intermittent feeding opportunities (Tremblay et al. 2012). Through vertical migrations, highly seasonal for copepods in the Arctic, and surface-to-benthic interactions, year-round for krill in the Antarctic, calanoids and krill play substantial roles in carbon and nutrient transport from the surface ocean to the seafloor (Darnis and Fortier 2012, Schmidt et al. 2011). In the Antarctic, krill, together with their much-depleted whale predators, probably played and play a very important role in the transport and availability of iron, a key micronutrient in polar ecosystems (Schmidt et al. 2011, Nicol et al. 2010); recovery of over-exploited whale populations could have a beneficial impact on Southern Ocean ecosystems through increased abundance of iron. The geographic distributions of these crustaceans, and of their prey and predators, play determinant roles in polar ecosystems and in the location and success of polar fisheries. In the Arctic relatively warm North Atlantic inflow carries abundant lipid-rich crustaceans to the Barents Sea, home of a rich fishery, while relatively cold water flowing through the Bering Strait carries relatively few high-energy crustacean food sources 
to the Chukchi Sea (Hunt et al. 2012). Along the Antarctic Peninsula, the krill-based ecosystems change as oceanic prey and predator species move south from subAntarctic islands (Murphy et al. 2012); these linked changes in environment and ecosystems will impact the growing krill fishery (Nicol et al. 2011). Predators follow the winter-time Arctic copepods into deep waters (Darnis et al. 2012). However, overall predation pressure on these crustaceans has changed substantially. In some cases abundances of non-exploited predator species such as Antarctic penguins (Trivelpiece et al. 2012) or Arctic auks (Berge et al. 2012) increased after humans harvested the baleen whales. Berge et al. (2012) suggest a new interpretation of calanoid life cycles as an evolved but relict response to now-absent predation. Whether they evolved in response to food abundance patterns or predation pressures, small life cycle variations among Arctic calanoid populations result in differing susceptibility to the combined stress of warming temperature and exposure to petroleum products (Hjorth and Nielsen 2011). These evolving observations and interpretations of crustacean ecology will prove crucial as ice, wind and ocean changes impact polar marine ecosystems.

\section{Track down the details at:}

- Berge J, Gabrielsen TM, Moline M, Renaud PE (2012) Evolution of the Arctic Calanus complex: an Arctic marine avocado? J Plankton Res. doi:10.1093/ plankt/fbr 103

- Carlson D (2012) ibid. doi:10.1007/s12665-011-1499-5

- Darnis G, Fortier L (2012) Zooplankton respiration and the export of carbon at depth in the Amundsen Gulf (Arctic Ocean). J Geophys Res. doi:10.1029/2011J C007374

- Darnis G et al. (2012) Current state and trends in Canadian Arctic marine ecosystems: II. Heterotrophic food web, pelagic-benthic coupling, and biodiversity. Climatic Change. doi:10.1007/s10584-012-0483-8

- Hjorth M, Nielsen TG (2011) Oil exposure in a warmer Arctic: potential impacts on key zooplankton species. Marine Biology. doi:10.1007/s00227-011-1653-3

- Hunt GL et al. (2012) The Barents and Chukchi Seas: Comparison of two Arctic shelf ecosystems. J Marine Systems. doi:10.1016/j.jmarsys.2012.08.003

- Leu E et al. (2011) Consequences of changing sea-ice cover for primary and secondary producers in the European Arctic shelf seas: Timing, quantity, and quality. Progress in Oceanography. doi:10.1016/ j.pocean.2011.02.004

- Murphy EJ et al. (2012) Comparison of the structure and function of Southern Ocean regional ecosystems: The Antarctic Peninsula and South Georgia. J of Marine Systems. doi:10.1016/j.jmarsys.2012.03.011
- Nicol S, Foster J, Kawaguchi S (2011) The fishery for Antarctic krill - recent developments. Fish and Fisheries. doi:10.1111/j.1467-2979.2011.00406.x

- Nicol S et al. (2010) Southern Ocean iron fertilization by baleen whales and Antarctic krill. Fish and Fisheries. doi:10.1111/j.1467-2979.2010.00356.x

- Schmidt, K et al. (2011) Seabed foraging by Antarctic krill: Implications for stock assessment, bentho-pelagic coupling, and the vertical transfer of iron. Limnol Oceanogr. doi:10.4319/lo.2011.56.4.1411

- Tremblay J-E et al. (2012) Current state and trends in Canadian Arctic marine ecosystems: I. Primary production. Climatic Change. doi:10.1007/s10584-0120496-3

- Trivelpiece WZ et al. (2012) Variability in krill biomass links harvesting and climate warming to penguin population changes in Antarctica. PNAS. doi: 10.1073/pnas.1016560108

\section{Communities and water}

In February 2012 (Carlson 2012), I advocated local and regional water strategies for northern communities. In May the Environment and Natural Resources Minister of Canada's Northwest Territories (NWT) described such a strategy at the IPY Conference in Montreal, and noted that the fact that the NWT had established a water strategy put it ahead of other jurisdictions. Northern communities and northern resource managers face a complicated future with respect to water. The extent of North American and Eurasian snow cover has decreased consistently for at least three decades (Derksen and Brown 2012, Shi et al. 2012), faster than the decrease in Arctic sea ice extent over the same time period and, as for sea ice, much faster than model predictions (Derksen and Brown 2012). Surface energy budgets and surface air temperatures play a large role in this decline; precipitation does not (Shi et al. 2012). Hydrologic models for the Alaska Arctic coastal plain indicate that most snow meltwater goes into storage (in lakes and soils) rather than into streamflow (Bowling and Lettenmaier 2010). Diminished snow extent can thereby translate into drier soils and annual lake storage deficits. Meanwhile, as floating ice regimes replace bedfast ice on many Arctic lakes (Arp et al. 2012), stored water becomes more accessible as over-winter aquatic habitat and winter water supply. Long-term hydrologic trends for northern lands remain distinctly uncertain. Continued mass loss in many northern glaciers reflects higher temperatures accompanied by almost no change in annual precipitation (Gardner et al. 2012). Ge et al. (2012) make similar warm and dry projections for Finnish forests. In contrast, model 
projections (from the same global climate models that fail to reproduce sea ice and snow extent decreases) for a western Canadian sub-Arctic watershed suggest small increases in annual river discharge due to enhanced spring runoff driven by snow melt and enhanced autumn runoff driven by precipitation (Todd et al. 2010). In a separate water balance modeling study, Kumar et al. (2012) suggest that extreme precipitation in the form of snow from less frequent but more intense winter storms partially offsets higher melt rates and changed rain/snow ratios, particularly in warm dry winters. Such a scenario of dry mean conditions punctuated by extreme precipitation events presents extraordinary challenges to resource (and transportation!) managers and to natural hydrological and ecological systems. The location, timing and intensity of such storms links directly to changing atmospheric circulation patterns described above.

\section{Track down the details at:}

- Arp CD, Jones BM, Lu Z, Whitman MS (2012) Shifting balance of thermokarst lake ice regimes across the Arctic Coastal Plain of northern Alaska. Geophys Res Lett. doi:10.1029/2012GL052518

- Bowling LC, Lettenmaier DP (2010) Modeling the effects of lakes and wetlands on the water balance of Arctic environments. J Hydrometeor. doi:10.1175/ 2009JHM1084.1

- Carlson D (2012) ibid. doi:10.1007/s12665-011-1499-5

- Derksen C, Brown R (2012) Spring snow cover extent reductions in the 2008-2012 period exceeding climate model projections. Geophys Res Lett. doi:10.1029/ 2012GL053387

- Gardner A, Moholdt G, Arendt A, Wouters B (2012) Accelerated contributions of Canada's Baffin and Bylot Island glaciers to sea level rise over the past half century. The Cryosphere. doi:10.5194/tc-6-1103-2012

- Ge Z-M et al. (2012) ibid. doi:10.1007/s10584012-0607-1
- Kumar M, Wang R, Link TE (2012) Effects of more extreme precipitation regimes on maximum seasonal snow water equivalent. Geophys Res Lett. doi:10.1029/ 2012GL052972

- Shi X, Déry SJ, Groisman PY, Lettenmaier DP (2012) Relationships between recent pan-Arctic snow cover and hydroclimate trends. J Climate. doi:10.1175/ JCLI-D-12-00044.1

- Todd MC et al. (2010) Quantifying the impact of climate change on water resources at the basin scale on five continents - a unified approach, Hydrol Earth Syst Sci. Discuss. doi:10.5194/hessd-7-7485-2010

\section{Summary}

Despite complexity and uncertainty, a compelling message emerges from evidence presented here: ice of some form (sea ice, glacier ice, snow) erodes or reduces or disappears, largely as a consequence of changes in atmosphere and ocean, with the result that global atmosphere and ocean systems change. As I write this, a predicted equatorial Pacific warm event (El Nino in ENSO terms) has unexpectedly paused. Or stopped. Or, perhaps even reversed? At the same time there occurs in polar regions: extreme Arctic sea ice loss, extraordinary Greenland surface melt, record Arctic Ocean temperatures, steady decline in Antarctic bottom water, continuing decrease in northern hemisphere snow coverage, ... Should we regard emerging uncertainties in tropical systems and changes in polar systems as coincidence? I think not. Anchors of the climate system at the warm (equatorial) and cold (polar) ends have come loose. In what direction(s) will the system drift? With what consequences for ecosystems and humanity? It remains challenging to determine cause from correlation and to quantify trends amidst variability, but we can anticipate the general directions and we know the major players: ocean, wind and ice. 